\title{
Appendix B
}

\section{Ideological features and themes}

Nationalism: The belief that the political unit (the state) and the cultural unit (the nation or ethnic community) should be congruent.

State nationalism: The state is the primary unit of organisation, while the nation consists essentially of the people living within the borders of the state. Membership of the nation is based on civic criteria like the ius soli and citizenship requirements.

Ethnic nationalism: The ethnic community is considered the primary unit, while the state is seen as essentially the political expression of the ethnic community. Membership of the ethnic community is based on ethnic criteria such as the ius sanguinis and ethnicity.

Internal homogenisation: Only people belonging to the X-nation have the right to live within the borders of the X-state. Foreigners are accepted only as (temporary) guests with limited rights; most notably, non-nationals are not allowed to have political rights.

External exclusiveness: State $\mathrm{X}$ needs to have all people belonging to the X-nation within its borders. The state is linked to an ethnic community, which again is linked to a certain territory.

Exclusionism: The distinction between groups whereby one group (they) is excluded from certain aspects of the life of the other group (we).

Racism: The belief in natural (hereditary) and permanent differences between groups of people with the centrality of a hierarchy of races.

Ethnopluralism: The belief in permanent (natural or hereditary) differences between groups of people (races and/or ethnic communities) with the centrality that all groups are equivalent but different; people should live within their own group and the groups should live separated; people have both the right and the duty to live according to their own 'natural way'.

Ethnocentrism: The belief in cultural and (in principle) temporal differences between groups of peoples, with the centrality that the own group is superior to the others.

Anti-semitism: The belief that the Jewish race or ethnic community is in its entirety bad; variants of a Jewish-led world conspiracy (in the tradition of the Protocols) with the conclusion that the Jews ('they') are essentially against the 'own group' ('us'). 
Xenophobia: Fear, hate or hostility with regard to groups that are perceived as 'alien' or 'strange', such as foreigners, immigrants, asylum-seeker, etc. The idea that anything 'alien' is threatening.

Anti-democratic features: Criticism of 'democracy' as a political system; views that are opposed to (various) core features of democracy (like pluralism, parliamentarism, political equality, etc.).

Elitism: The belief that people are divided by birth into leaders and followers; a small elite should lead the masses without their interference; the common man is not able to decide on difficult matters (such as politics).

Führerprinzip: One person is gifted by nature with the qualities that good leadership requires. This leader is the heart of the (ethnic) community and has absolute power. His leadership is above discussion, as only he is able to decide what is good and bad for the (ethnic) community.

Monism: The tendency to treat cleavage and ambivalence as illegitimate; rejection of contradistinctions within the (ethnic) community and the state are not accepted; the part (individual) is nothing without the whole (state) and they thus have the same interests.

Organic vision of the state: The state is regarded as an organism. This means that one is born into it, and that one has a fixed role to play in the state; it further implies a hierarchic order; Fremdkörper, i.e. people who do not perform their correct role or who do not have a role to play in the state, make the state ill and have to be taken out of the process.

Technocracy: Technocrats, i.e. people who are not elected but are qualified on the basis of their skills, should have a leading role in political and economic matters.

Populism: The belief in the soundness of the common man; anti-elitism; support for direct democratic measures on the basis of letting the people decide; call for referendums at various levels and to go back to the grass-roots.

Anti-party sentiments: Systematic criticism of political parties, directed either at the institution itself or at the policies and behaviour of 'the' political parties.

Extremist anti-party sentiments: The political party as an institution is rejected, often on the grounds of its divisive nature or on the basis of the fact that it forms a barrier between the rulers and the ruled.

Populist anti-party sentiments: Certain political parties (usually the major or established parties) are rejected, often because of their bad functioning or because of the group they (do not) represent.

\section{The strong state}

Law-and-order: The belief in order and authority, accompanied by the demand for strong punishment of breach of the rules (e.g. high sentence, sober prison conditions, capital punishment); to maintain order the state should have a strong police force in terms of personnel, equipment and competencies.

Militarism: The call for a strong army to protect the national interests; serving in the army as the highest honour; war is considered the natural condition; peace is considered an artificial period between wars; war is considered to be more than a means to pursue the 'national will' as it is the ultimate goal. Positive and unique attributes are ascribed to war and the soldier functions as a role model. 


\section{Environmental position}

Ecologism: The vision that nature should be carefully exploited by men; the search for a balance between economic growth and environmental protection; warning for the exhaustion of natural resources; criticism of economic growth at all costs; the belief in technology and human inventions to reach this goal.

Environmentalism: The vision that nature is equal to man and should be treated with the same respect; no attack on nature on the basis of materialist arguments; the belief that this can only be realised by a new way of thinking (i.e. the rejection of the belief in progress through expansion) and not solely by technological improvements.

\section{Ethical outlook}

Traditional ethics: Concern with the breakdown of the nucleus family, community, religion, and traditional morality from a non-religious viewpoint; values are grown as historical basis of society and their decline means the breakdown of society. For a strict ban on non-ethical behaviour (pornography, abortion, homosexuality); a plea for duties, honour, order, dignity etc. over materialist and hedonist motives.

Religious ethics: Concern with the breakdown of religious values as the backbone of society; emphasis on a combination of values like the nucleus family, community and religious morality; opposition to modernisation of the Church.

Libertarianism: Putting the autonomous individual and his rights and duties at the centre; support for freedom of choice (abortion, euthanasia, drugs); opposition to state regulation state of ethical questions.

\section{Socio-economic policy}

Corporatism/solidarism: Support for trilateral governing, which involves the state as well as the workers and the employers; economy should come to the good of the whole nation and not to specific groups; national solidarity instead of class struggle.

(Neo-)Liberalism: Strong belief in the natural working of the market; a minimum of state intervention in the economy; deregulation of economy; support of private enterprise; strong emphasis on freedom and individualism.

Socialism: Support of strong state control over sectors of the economy; support of strict and detailed planning of the economy; nationalisation of vital sectors of the national economy.

Welfare chauvinism: Socio-economic policy should be directed first and foremost to the 'own group'. Priority in jobs and social benefits for the own people. State protection of certain areas of the national economy against foreign competition. 